\begin{tabular}{|l|l|l||}
\hline \multicolumn{2}{|c|}{ PublisherInfo } \\
\hline \hline PublisherName & $:$ & Palgrave Macmillan UK \\
\hline \hline PublisherLocation & $:$ & London \\
\hline \hline PublisherImprintName & $:$ & Palgrave Macmillan \\
\hline \hline
\end{tabular}

\title{
Multi-factor productivity analysis
}

\begin{tabular}{|l|l|l||}
\hline \multicolumn{3}{|c|}{ ArticleInfo } \\
\hline \hline ArticleDOI & $:$ & $10.1057 /$ palgrave.elmr.1410106 \\
\hline \hline ArticleCategory & $:$ & Feature \\
\hline \hline ArticleFirstPage & $:$ & 32 \\
\hline \hline ArticleLastPage & $:$ & 38 \\
\hline \hline & & RegistrationDate $: 2007-7-20$ \\
ArticleHistory & $:$ & OnlineDate $\quad$ 2007-7-20 \\
\hline \hline ArticleCopyright & $:$ & Crown copyright2007 \\
\hline \hline
\end{tabular}




\section{Presents a multi-factor productivity analysis, using an experimental quality-adjusted labour input measure and experimental estimates of capital services growth as inputs.}

This article presents multi-factor productivity, sometimes referred to as total factor productivity or growth accounting, results for 1997 to 2005 using an experimental quality-adjusted labour input measure and experimental estimates of capital services growth as inputs. The analysis has been produced for the whole economy and some broad industry groupings, with the aim of better understanding the UK's productivity performance over this period and of usingthe results as a diagnostic check on the consistency of output and input data.

The Full Text of this article can be found on the National Statistics website (http://www.statistics.gov.uk/elmr/07_07/downloads/ELMR_July07_Goodridge.pdf). 